\title{
Kajian Pengembangan Unit Usaha Klinik Hemodialisa Skala Usaha Kecil Menengah Berbasis Badan Penyelenggara Jaminan Sosial Kesehatan
}

\author{
Strategy Development Business Unit Hemodialysis Clinic-Based Small and Medium Scale \\ Social Security Agency of Health
}

\author{
Wiwi Kania Dewi ${ }^{1 *}$, Musa Hubeis ${ }^{2 *}$, dan Fransiska R. Zakaria ${ }^{3 \#}$ \\ ${ }^{1}$ Kualita Citra Sertifikasi \\ ${ }^{2}$ Departemen Manajemen, Fakultas Ekonomi Manajemen, Institut Pertanian Bogor \\ ${ }^{3}$ Departemen Ilmu dan Teknologi Pangan, Fakultas Teknologi Pertanian, Institut Pertanian Bogor \\ *Jl. Kamper Kampus IPB Darmaga, Bogor 16680
}

\begin{abstract}
ABSTRAK
Indonesia merupakan salah satu negara dengan angka gagal ginjal cukup tinggi. Perkumpulan Nefrologi Indonesia (PERNEFRI) dalam $5^{\text {th }}$ Report of Indonesian Renal Registry pada tahun 2012 melaporkan terdapat 16.040 penderita gagal ginjal, tetapi hanya 9.161 pasien yang aktif dalam kegiatan hemodialisa. Tujuan penelitian adalah (1) mengidentifikasi faktor internal dan eksternal potensi unit usaha klinik hemodialisa skala usaha kecil menengah (UKM) berbasis BPJS Kesehatan, (2) menyusun strategi dengan analisis SWOT unit usaha klinik hemodialisa skala UKM berbasis BPJS Kesehatan dan (c) menganalisis kepuasan pasien dari klinik hemodialisa berbasis BPJS Kesehatan. Teknik sampling dengan metode judgement sampling, yaitu dengan cara memilih konsumen yang paling tepat untuk memberikan informasi yang dibutuhkan. Jumlah contoh yang diteliti sebanyak 30 responden. Pengolahan dan analisis data meliputi: (1) analisis matriks EFE (External Factor Evaluation) danIFE (Internal Factor Evaluation); (2) matriks Internal External (IE); (3) analisis SWOT (Strengths, Weaknesses, Opportunities and Threats); (4) Importance Performance Analysis (IPA); dan (5) Customer Satisfaction Index (CSI). Hasil penelitian menunjukkan nilai EFE $(2,73)$ dan IFE $(2,61)$, didapatkan matriks IE yang menunjukkan posisi Pertumbuhan/Stabil. Analisis SWOT menghasilkan enam alternatif strategi pengembangan yang dapat diimplementasikan dalam rangka pengembangan unit usaha. Dari kajian IPA, ditemui bahwa kinerja unit usaha dinilai baik, dimana terdapat hampir setengah dari atribut yang dikaji berada pada kuadran kedua. Hal ini menunjukkan penilaian tingkat kepentingan terhadap atribut tersebut dianggap penting oleh pasien dan dalam pelaksanaannya dinilai sudah sangat baik. Skor CSI 0,920, menunjukkan tingkat indeks kepuasan pelanggan terletak pada $0,81-1,00$, atau diartikan pelanggan merasa sangat puas terhadap unit usaha klinik hemodialisa skala UKM.
\end{abstract}

Kata kunci: hemodialisa skala UKM, kepuasan pelanggan, pengembangan strategi

\section{ABSTRACT}

Indonesia is one country with the kidney failure is quite high, according to the Indonesian Society of Nephrology (PERNEFRI) in the 5th Report of Indonesian Renal Registry, in 2012 there were 16.040 patients with kidney failure but reportedly only 9161 patients were active in hemodialysis in 2012. The purpose of research is (a) identifying the internal and external factors potential business unit clinic hemodialysis-based BPJS Health, (b) develop appropriate strategies with a SWOT analysis of the business unit clinic hemodialysis-based BPJS and (c) to analyze the satisfaction of patients who use the clinic hemodialysis-based BPJS Health. Data processing and analysis using the analysis: (a) analysis matrix EFE (External Factor Evaluation) and IFE (Internal Factor Evaluation), (b) matrix Internal External (IE); (c) a SWOT analysis (Strengths, Weaknesses, Opportunities and Threats); (d) Importance Performance Analysis (IPA), and Customer Satisfaction Index (CSI). EFE value (2.73) and IFE (2.61) obtained IE matrix

\footnotetext{
*) Korespondensi:

Cibubur Times Square Jl. Transyogie Blok C1 no. 26 Jakarta; email: kaniadewidewi@ymail.com
} 
that shows the position of growth/stable. SWOT analysis produce six alternative development strategies that can be implemented in the development of the business unit. From the study of IPA to attribute asked to patients, it was found that the performance of the business unit is considered good, where there are nearly half of the attributes that were examined are in the second quadrant. This shows the importance of the assessment of the attributes considered important by patients and in its implementation is considered to be very good. CSI score of 0.920 , indicating the level of customer satisfaction index is at 0.81 to 1.00 , or interpreted the customer was very satisfied with the business unit of the hemodialysis clinics SME scale.

Key words: customer satisfaction, formulation strategies, hemodialysis

\section{PENDAHULUAN}

Penanganan penyakit ginjal dapat dilakukan dengan berbagai cara, mulai dari pengendalian tekanan darah, pengaturan diet, terapi farmakologis, pemberian kartisol 1.25 (OH2D3), pembatasan cairan dan elektrolit, hingga Terapi Pengganti Ginjal (Renal Replacement Therapy/RRT) yang dapat berupa hemodialisis (HD), peritoneal dialysis atau transplantasi ginjal. Penyakit Ginjal Kronik (PGK) adalah suatu proses patofisiologis dengan etiologi beragam, mengakibatkan penurunan fungsi ginjal progresif dan pada umumnya berakhir dengan gagal ginjal. Selanjutnya, gagal ginjal adalah suatu keadaan klinis yang ditandai dengan penurunan fungsi ginjal irreversible, pada suatu derajat yang memerlukan terapi pengganti ginjal tetap, berupa dialysis atau transplantasi ginjal. Untuk kasus pasien gagal ginjal kronik, bila faal ginjal yang masih tersisa sudah minimal, maka obat-obatan dan lain-lain tidak memberi pertolongan yang diharapkan lagi. Keadaan tersebut diberi nama gagal ginjal terminal. Pasien gagal ginjal kronik, atau etiologi penyakit ginjalnya, memerlukan pengobatan khusus yang disebut pengobatan atau terapi pengganti (RRT) (PERNEFRI, 2003). Gejala gangguan fisik yang sering dikeluhkan pasien PGK yang menjalani HD adalah kelelahan, tidak tahan cuaca dingin, pruritus, kelemahan ekstremitas bawah, dan kesulitan tidur (Yong, Kwok and Wong, 2009). Hasil penelitian Santos et al (2012), dari total 58 pasien perempuan yang menjalani HD, 46 (79,3\%) diketahui mengalami disfungsi seksual.

Peran sektor swasta dalam pelayanan HD cukup besar $(43,5 \%)$ dan tidak menutup kemungkinan adanya kerjasama dengan Badan Penyelenggara Jaminan Sosial (BPJS) Kesehatan dalam segi sumber pendanaan atau pembiayaan. Dalam hal ini, sektor swasta bukan hanya memiliki peran sosial, namun harus dapat mempertahankan dirinya sendiri dalam era globalisasi yang semakin ketat, maka diperlukan strategi yang tepat untuk mengembangkan dan meningkatkan usaha HD ini. HD adalah suatu prosedur dimana darah dikeluarkan dari tubuh penderita dan beredar dalam sebuah mesin di luar tubuh yang disebut dialiser (Supriyadi, Wagiyo dan Widowati, 2011).

Tujuan penelitian ini adalah (1) mengidentifikasi faktor internal dan eksternal potensi unit usaha klinik HD berbasis BPJS Kesehatan, (2) menyusun strategi yang tepat dengan analisis SWOT dari unit usaha klinik HD skala UKM berbasis BPJS Kesehatan dan (3) menganalisis kepuasan pasien yang menggunakan klinik HD skala UKM berbasis BPJS Kesehatan.

\section{METODE PENELITIAN}

Penelitian dilakukan di Klinik HD skala UKM RS Satya Bhakti Depok, Jawa Barat, dimulai pada bulan September sampai dengan Desember 2014.

\section{Pengolahan dan Analisis Data}

1. Matriks EFE (External Factor Evaluation) dan IFE (Internal Factor Evaluation).

Matriks EFE membantu pengambilan keputusan untuk meringkas dan mengevaluasi informasi lingkungan eksternal, yaitu ekonomi, sosial, budaya, demografi, lingkungan, politik, pemerintah, teknologi, dan sebagainya. Matriks IFE digunakan untuk meringkas dan mengevaluasi kekuatan dan kelemahan utama yang dihadapi perusahaan.

2. Matriks Internal-External (IE)

Matriks IE digunakan untuk melakukan pemetaan terhadap skor total matriks IFE dan EFE yang dihasilkan dari audit eksternal dan internal perusahaan. Matriks IE terdiri atas dua dimensi, yaitu total skor dari matriks IFE dan total skor matriks EFE. Total skor matriks IFE dipetakan pada sumbu $\mathrm{X}$ dengan skor 1,01,99 yang menyatakan posisi internal adalah 
lemah, skor 2,0-2,99 posisinya rataan, serta skor 3,0-4,0 adalah posisi kuat.

3. Analisis SWOT

Menurut Rangkuti (2013), hampir setiap perusahaan maupun pengamat bisnis dalam pendekatannya banyak menggunakan analisis SWOT. Analisis ini mengidentifikasi berbagai faktor secara sistematik untuk merumuskan strategi perusahaan. Analisis ini didasarkan pada logika untuk memaksimalkan kekuatan (strengths) dan peluang (opportunities), namun secara bersamaan dapat meminimalkan kelemahan (weaknesses) dan ancaman (threats).

4. Customer Satisfaction Index (CSI)

Hendriyani (2010), menyatakan bahwa Customer Satisfaction Index (CSI) adalah fungsi dari weighted average (WA) dibagi highest scale (HS) atau skala maksimum yang dipakai dalam penelitian ini (skala 5) dikalikan 100\%. Kriteria indeks kepuasan pelanggan (IKP) menggunakan kisaran 0,00-1,00 (tidak puas hingga puas), dilihat pada Tabel 1.

Tabel 1. Kriteria nilai CSI

\begin{tabular}{l|l}
\hline Nilai IKP & Kriteria \\
\hline $0,00-0,34$ & Tidak puas \\
$0,35-0,50$ & Kurang puas \\
$0,51-0,65$ & Cukup puas \\
$0,66-0,80$ & Puas \\
$0,81-1,00$ & Sangat puas \\
\hline
\end{tabular}

5. Importance Performance Analysis (IPA)

Menurut Umar (2003), IPA merupakan metode yang dapat digunakan untuk menganalisis respon konsumen secara deskriptif kuantitatif. Data skala likers diberi skor secara kuantitatif untuk dipakai dalam perhitungannya (Tabel 2). Matriks IPA yang digunakan merupakan suatu bangun yang dibagi menjadi empat kuadran yang dibatasi oleh dua buah garis berpotongan tegak lurus.

Tabel 2. Skor tingkat kepentingan

\begin{tabular}{lc}
\hline \multicolumn{1}{c}{ Kriteria Jawaban } & Skor (Nilai) \\
\hline Tidak penting & 1 \\
Kurang penting & 2 \\
Cukup penting & 3 \\
Penting & 4 \\
Sangat penting & 5 \\
\hline
\end{tabular}

\section{HASIL DAN PEMBAHASAN}

RSIA Setya Bhakti adalah rumah sakit ibu dan anak swasta yang merupakan anak dari Yayasan Husada Bhakti. Dengan didukung para dokter ahli dari berbagai disiplin ilmu RSIA Setya Bhakti siap memberikan pelayanan kesehatan terbaik. RSIA Setya Bhakti beralamat di Jl. Raya Bogor Km. 30 Mekarsari, Cimanggis-Depok. RSIA Setya Bhakti memiliki fasilitas kesehatan sebagai berikut:

1. Poli Umum

2. Poli Kebidanan

3. Poli Anak

4. Poli Gigi

5. Poli Kulit dan Kelamin

6. Laboratorium

7. Rontgen

Sampai pada saat ini, RSIA Setya Bhakti telah bekerjasama dengan sembilan asuransi kesehatan dan jaminan perusahaan. Nama-nama provider asuransi yang telah bekerjasama dengan Klinik Utama Setya Bhakti:

1. BPJS Kesehatan

2. Asuransi In health

3. Asuransi Tugu Mandiri (AdMedik)

4. Asuransi Nayaka

5. Asuransi Bringin Life

6. Asuransi CIU

7. Asuransi Gessa Assistance

8. Asuransi Bintang

9. Jaminan Perusahaan PT PRALON

\section{Hasil Analisis}

\section{Matriks IFE dan EFE}

Berdasarkan analisis lingkungan eksternal dan internal, diperoleh hasil berupa nilai matriks yang menentukan posisi unit usaha klinik hemodialisa skala UKM untuk dijadikan acuan dalam memformulasikan alternatif strategi yang diperoleh. Perumusan strategi pemasaran ini tidak terlepas dari aspek dimensi lingkungan eksternal dan internal.

Berdasarkan hasil penjumlahan skor total pada matriks IFE dan EFE didapatkan nilai masing-masing 2,61 dan 2,73. Skor total yang terdapat pada matriks EFE menggambarkan dengan rataan 2,0-3,0, sehingga mengindikasikan posisi unit usaha klinik HD skala UKM stabil dalam merespon situasi eksternal yang dihadapi. Skor total IFE mengindikasikan posisi unit usaha klinik HD skala UKM berada pada tingkat rataan 
untuk mampu merespon iklim internal yang dimiliki.

Nilai skor total kombinasi antara matriks EFE dan IFE digunakan untuk mengetahui posisi unit usaha klinik HD (Gambar 1). Berdasarkan kombinasi dari nilai EFE dan IFE didapatkan matriks IE. Nilai matriks IE menun-jukkan pada posisi sel tengah (Pertumbuhan/ Stabil).

\section{Matriks IE}

Penentuan posisi strategi perusahaan dalam matriks IE didasarkan pada hasil total nilai matriks IFE yang diberi bobot pada sumbu $x$ dan total nilai matriks EFE pada sumbu y (David, 2006). Posisi matriks IE menunjukkan posisi strategi pertumbuhan dan stabilitas. Strategi pertumbuhan didesain untuk mencapai kondisi pertumbuhan penjualan, pertumbuhan keuntungan dan pertumbuhan aset. Usaha yang dapat dilakukan adalah penetrasi pasar dan pengembangan usaha.

Kegiatan untuk peningkatan pemasaran dan pelayanan merupakan salah satu formulasi strategi yang dapat menjadi andalan utama bagi klinik HD, disamping mengembangkan kegiatan usaha yang juga bertujuan mem-pertahankan usaha, agar terus berlangsung dan terhindar dari kehilangan pasien. Hasil identifi-kasi dari kekuatan, kelemahan, peluang dan ancaman perusahaan digunakan untuk merumus-kan alternatif strategi dengan menggunakan matriks SWOT.

\section{Perumusan Strategi SWOT}

Perumusan strategi diterapkan melalui identifikasi dan analisis faktor-faktor eksternal yang terdiri dari peluang dan ancaman, serta faktor-faktor internal yang terdiri dari kekuatan dan kelemahan. Peluang merupakan situasi yang diinginkan atau disukai dalam lingkungan industri. Ancaman merupakan situasi yang tidak diinginkan atau tidak disukai dalam lingkungan industri. Kekuatan merupakan kompensasi khusus yang memberikan keunggulan komperatif bagi klinik HD skala UKM, sedangkan kelemahan merupakan keterbatasan atau kekura-ngan dalam sumber daya keterampilan, maupun kemampuan yang dapat menghambat kinerjanya.

Perumusan strategi dilakukan dengan mengkombinasikan berbagai faktor yang telah diidentifikasi dan dikelompokkan. Hasil perumusan dikelompokkan menjadi empat kelompok perumusan strategi yang terdiri dari strategi Kekuatan-Peluang (S-O), strategi KekuatanAncaman (S-T), Strategi Kelemahan-Peluang (WO) dan strategi Kelemahan-Ancaman (W-T), seperti termuat pada Gambar 2.

Penyusunan mekanisme operasional merupakan batasan kegiatan yang perlu dilakukan oleh perusahaan dalam proses pengembangan usaha dan pemeliharaan klinik HD skala UKM. Formulasi kebijakan kualitatif pada Gambar 2 dapat dirumuskan berikut:

a. Strategi S-O (kombinasi S1-S3 dengan O1-O4)

Strategi ini didapatkan dengan memanfaatkan dan memaksimalkan kekuatan yang dimiliki oleh usaha klinik HD skala UKM untuk mengambil atau memanfaatkan peluang yang ada. Berdasarkan hasil analisis diperoleh formulasi strategi, yaitu permintaan semakin tinggi dan mutu hubungan antara Rumah Sakit dan BPJS akan menghasilkan output layanan baik, mengingat tipe RS yang dapat merangkul semua kalangan.

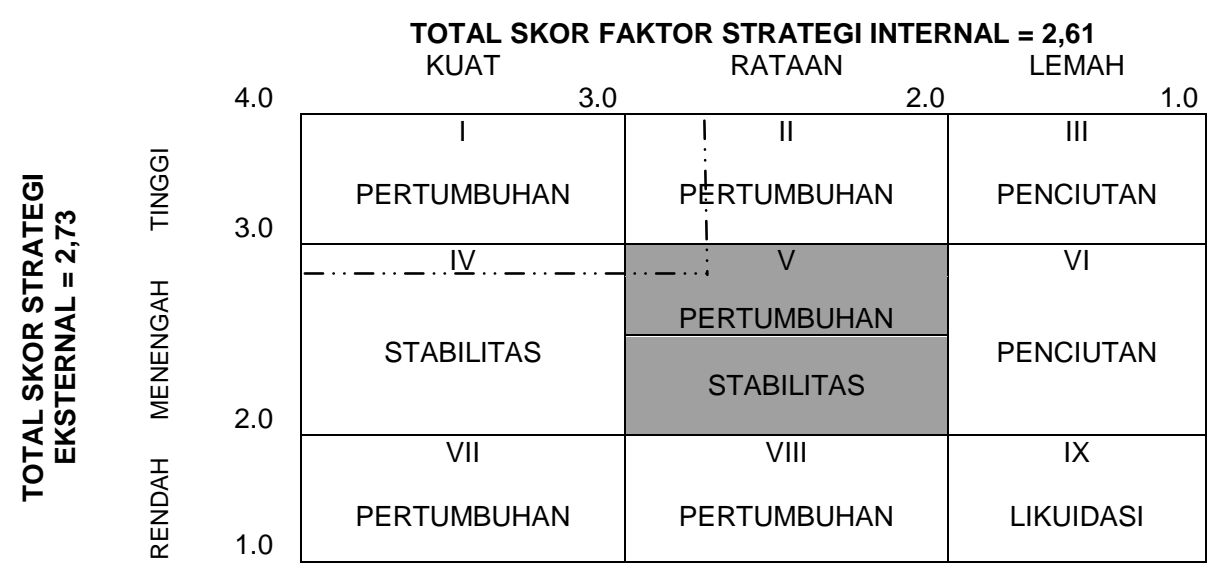

Gambar 1. Analisis Matriks IE 


\begin{tabular}{|c|c|c|}
\hline Faktor Eksternal & $\begin{array}{l}\text { Faktor kekuatan (S) } \\
\text { 1. RSIA Setya Bhakti sudah terkenal dan } \\
\text { berdiri sejak tahun } 1983 \\
\text { 2. Adanya tempat untuk klinik HD } \\
\text { 3. Luas dan besar ruangan yang disiapkan } \\
\text { sangat memadai } \\
\text { 4. Fasilitas dan peralatan medik dasar } \\
\text { sudah memadai } \\
\text { 5. Adanya dokter spesialis bersertifikat } \\
\text { pelayanan hemodialisa } \\
\text { 6. Lokasi strategik di Jalan Raya Bogor } \\
\text { 7. Rumah Sakit buka } 24 \text { jam }\end{array}$ & $\begin{array}{l}\text { Faktor kelemahan }(\mathbf{W}) \\
\text { 1. Belum adanya perawat } \\
\text { bersertifikat HD } \\
\text { 2. Belum adanya alat/mesin } \\
\text { hemodialisa } \\
\text { 3. Belum ada kepercayaan } \\
\text { masyarakat terhadap adanya } \\
\text { klinik HD }\end{array}$ \\
\hline $\begin{array}{l}\text { Faktor peluang }(\mathrm{O}) \\
\text { 1. RS tipe } \mathrm{D} \text {, sehingga untuk pelayanan } \\
\text { berjenjang memiliki kesempatan lebih } \\
\text { banyak } \\
\text { 2. Tingkat kepercayaan terhadap RS tinggi } \\
\text { 3. Hubungan dan kerjasama yang baik } \\
\text { dengan BPJS } \\
\text { 4. Kebutuhan masyarakat sekitar tinggi } \\
\text { akan pelayanan HD } \\
\text { 5. Belum adanya RS tipe D yang membuka } \\
\text { pelayanan HD berbasis BPJS }\end{array}$ & \begin{tabular}{l}
\multicolumn{1}{c}{ Strategi SO (agresif) } \\
Permintaan semakin tinggi dan mutu \\
hubungan antara RS dan BPJS akan \\
menghasilkan output layanan yang baik, \\
mengingat tipe RS yang dapat \\
merangkul semua kalangan \\
(S1,S2,S3,S4,S5,S6,S7,O1,O2,O3,O4,O5)
\end{tabular} & $\begin{array}{l}\text { Strategi WO (diversifikasi) } \\
\text { Membangkitkan } \\
\text { kepercayaan masyarakat } \\
\text { terhadap layanan dan RS } \\
\text { akan meningkatkan dan } \\
\text { mengadakan lebih banyak } \\
\text { alat HD,serta mengadakan } \\
\text { perawat bersertifikat (W1, } \\
\text { W2,W3,O1,O2,O3,O4,O5) }\end{array}$ \\
\hline $\begin{array}{l}\text { Faktor ancaman }(\mathrm{T}) \\
\text { 1. Adanya RS sekitar penyedia HD } \\
\text { 2. Belum adanya investor tetap untuk } \\
\text { layanan HD } \\
\text { 3. Adanya anggapan masyarakat negatif } \\
\text { tentang RS tipe D }\end{array}$ & $\begin{array}{l}\text { Strategi ST (diferensiasi) } \\
\text { 1. Meningkatkan daya saing RS untuk } \\
\text { memberikan pelayanan yang lebih baik } \\
\text { daripada RS sekitar penyedia HD } \\
\text { (S1,S2,S3,S4,S5,S6.S7.T1) } \\
\text { 2. Menarik investor untuk menginves- } \\
\text { tasikan dana untuk pelaksanaan klinik } \\
\text { HD skala UKM } \\
\text { (S1,S2,S3,S4,S5,S6,S7,T2) } \\
\text { 3. Mutu yang diberikan RSIA Setya } \\
\text { Bhakti akan menanggalkan anggapan } \\
\text { negatif tentang RS tipe D } \\
\text { (S1,S2,S3,S4,S5,S6,S7,T3) }\end{array}$ & $\begin{array}{l}\quad \text { Strategi WT (defensif) } \\
\text { Meningkatan mutu dengan } \\
\text { mengadakan lebih banyak alat } \\
\text { dialisis dan perawat } \\
\text { bersertifikat terkait persaingan } \\
\text { yang ada dengan RS sekitar } \\
\text { penyedia HD } \\
\text { (W1,W2,W3,T1,T2,T3) }\end{array}$ \\
\hline
\end{tabular}

Keterangan : - $(\mathrm{Oi} ; \mathrm{Si})$ atau $(\mathrm{Oi} ; \mathrm{Wi})$ atau $(\mathrm{Ti} ; \mathrm{Si})$ atau $(\mathrm{Ti} ; \mathrm{Wi})$ menunjukkan kombinasi lingkungan eksternal dengan internal dalam menghasilkan pilihan strategi.

$-\mathrm{i}=1,2, \ldots \ldots . . . \mathrm{n}$.

Gambar 2. Rumusan strategi pemasaran dengan matriks SWOT

\section{b. Strategi S-T (kombinasi S1-S3 dengan T1-T5)}

Strategi ini didapatkan dengan memaksimalkan kekuatan yang dimiliki perusahaan dalam mengantisipasi ancaman. Berdasarkan hasil analisis diperoleh beberapa formulasi strategi, yaitu meningkatkan daya saing RS untuk memberikan pelayanan yang lebih baik daripada RS sekitar penyedia HD skala UKM, menarik investor untuk menginvestasikan dana untuk pelaksanaan klinik HD skala UKM, serta mutu yang diberikan RSIA Setya Bhakti akan menanggalkan anggapan negatif tentang Rumah Sakit tipe D. Hasil penelitian menunjukkan bahwa penyakit gagal ginjal kronis masih menjadi masalah besar di dunia, karena selain sulit disembuhkan, biaya perawatan dan pengobatannyapun sangat mahal (Chen et al., 2009; Russell et al., 2011).

\section{c. Strategi W-O (kombinasi W1-W3 dengan O1- O4)}

Strategi ini didapatkan dengan usaha menekan atau meminimalisasi kelemahan yang dimiliki unit usaha klinik HD skala UKM untuk memanfaatkan peluang yang ada saat ini, strateginya dengan membangkitkan kepercayaan masyarakat terhadap pelayanan RS dan mengadakan lebih banyak alat HD, serta mengadakan perawat bersertifikat dan berpengalaman. Hal ini perlu dilakukan, mengingat proses HD membutuhkan waktu 4-5 jam dan umumnya akan menimbulkan stres fisik, pasien akan merasakan kelelahan, sakit kepala dan keluar keringat dingin akibat tekanan darah yang menurun (Gallieni et al., 2008; Orlic et al., 2010). Sulistini et al (2012) juga berpendapat bahwa pasien yang menjalani HD cenderung mengalami kelelahan, sehingga 
perawat dalam memberikan intervensi selalu menggunakan pendekatan holistik untuk mendapatkan hasil yang efektif dalam pemberian asuhan keperawatan.

\section{d. Strategi W-T (kombinasi W1-W3 dengan T1-} T5)

Strategi yang dapat dilakukan melalui upaya meminimalisasi kelemahan yang dimiliki unit usaha klinik HD skala UKM untuk mengantisipasi ancaman atau untuk menghadapi kemungkinan ancaman yang ada dari lingkungan eksternal usaha. Strateginya dengan meningkatkan mutu, yaitu mengadakan lebih banyak alat dialisis dan menyediakan perawat bersertifikat dengan memperhatikan persaingan dengan RS sekitar penyedia HD. Seperti diketahui, bahwa berbagai negara telah meneliti tentang mutu hidup pasien PGK yang menjalani HD dan hasil penelitiannya menunjukkan mutu hidup pasien buruk. Untuk itu perlu dilakukan penilaian secara teratur tentang mutu hidup pasien yang menjalani HD dengan menggunakan instrumen yang tepat (Mailani, 2015).

\section{Analisis CSI}

Kepuasan pelanggan akan timbul jika kebutuhan dan keinginan pelanggan dapat terpenuhi oleh produk bermutu. Puas atau tidaknya pelanggan terhadap suatu produk ditentukan oleh perilaku yang tampak setelah menggunakan produk tersebut. Pada umumnya bila pelanggan merasa puas terhadap suatu produk, maka akanmelakukan pembelian ulang terhadap produk tersebut. Bila hal ini terjadi, maka akan menimbulkan kesetiaan dari pelanggan terhadap produk tersebut. Pelanggan yang puas akan memberikan keuntungan bagi perusahaan yaitu akan mengurangi persaingan terhadap barang dan merk sejenis.

Dari Tabel 3, didapatkan atribut yang memiliki nilai rataan tingkat kepentingan dengan rating empat (4) yang tinggi adalah atribut (25) legalitas sesuai pelaksanaan, (20) alokasi anggaran bagi pengembangan kegiatan, (32) dampak ekonomi masyarakat dan (30) Sumber Daya Manusia (SDM) sudah memenuhi. Nilai rataan tingkat kepentingan dan tingkat kepuasan masing-masing atribut mutu jasa digunakan untuk menghitung CSI. Berdasarkan perhitungan yang terdapat pada Tabel 4 didapatkan hasil CSI 0,920 . Hal ini menunjukkan bahwa tingkat indeks kepuasan pelanggan terletak pada 0,81-1,00, maka pelanggan merasa sangat puas terhadap klinik HD skala UKM.

Rincian analisis dari masing-masing atribut-atribut yang dikaji pada Tabel 4 adalah:

a. Legalitas sesuai pelaksanaan

Legal artinya ketentuan sesuai dengan peraturan. Dalam klinik HD, pelaksanaan sesuai dengan ketentuan yang berlaku, maka masyarakat merasa aman dan nyaman dalam menggunakan fasilitas HD di RSIA Setya Bhakti. Oleh karena itu, legalitas sesuai pelaksanaan menjadi rating tertinggi tingkat kepentingan. Tingkat kepentingan terhadap atribut ini dinilai sangat penting dengan nilai 4,7 dan penilaian kinerja dengan nilai 4.8, dengan skor tertimbang 0,151. Atribut ini menduduki peringkat pertama, sehingga layak untuk dipertahankan.

\section{b. Alokasi anggaran bagi pengembangan kegiatan}

Dalam pengembangan unit usaha klinik HD skala UKM diperlukan anggaran yang sangat besar, sehingga penggunaan anggaran tersebut diharapkan dapat sesuai dengan kebutuhan dan dengan semakin banyaknya masyarakat yang menggunakan klinik HD skala UKM, maka pengembangan kegiatan usaha tersebut dapat berkembang dan maju. Oleh karena itu, alokasi anggaran bagi pengembangan kegiatan sangat diperhatikan pengelola dalam unit usaha klinik hemodialisa skala UKM. Tingkat kepentingan terhadap atribut ini dinilai penting dengan nilai 4,7 dan penilaian kinerja dengan nilai 4,8, dengan skor tertimbang 0,151. Atribut ini menduduki peringkat kedua sehingga layak untuk dipertahankan.

c. Dampak ekonomi masyarakat

Dalam pengembangan unit usaha klinik HD skala UKM diharapkan dapat memberikan dampak ekonomi masyarakat, khususnya stakeholder sekitar, seperti RSIA Setya Bhakti dan pengguna HD. Sasaran utama dalam unit usaha klinik hemodialisa skala UKM adalah masyarakat yang menggunakan jaminan BPJS, sehingga masyarakat lapisan menengah ke bawah dapat menggunakan jaminannya tanpa merasa terbebani dengan biaya HD. Tingkat kepentingan terhadap atribut ini dinilai penting dengan nilai 4,7 dan penilaian kinerja dengan nilai 4,8, dengan skor tertimbang 0,148. Atribut ini menduduki peringkat ketiga, sehingga layak dipertahankan. 
Tabel 3. Perhitungan CSI

\begin{tabular}{|c|c|c|c|c|c|}
\hline $\begin{array}{l}\text { Nomor } \\
\text { Atribut }\end{array}$ & $\begin{array}{c}\text { Skor rataan } \\
\text { Tingkat } \\
\text { Kepentingan }\end{array}$ & $\begin{array}{c}\text { Importance } \\
\text { Weighting } \\
\text { Factor }\end{array}$ & $\begin{array}{l}\text { Importance } \\
\text { Weighting } \\
\text { Factor (\%) }\end{array}$ & $\begin{array}{c}\text { Skor rataan } \\
\text { Tingkat } \\
\text { Kinerja }\end{array}$ & Weighted Score \\
\hline 1. & 4,6 & 0,030 & 3,062 & 4,8 & 0,146 \\
\hline 2. & 4,6 & 0,030 & 3,029 & 4,5 & 0,136 \\
\hline 3. & 4,4 & 0,028 & 2,897 & 4,7 & 0,136 \\
\hline 4. & 4,6 & 0,030 & 3,062 & 4,8 & 0,146 \\
\hline 5. & 4,3 & 0,028 & 2,864 & 4,5 & 0,128 \\
\hline 6. & 4,5 & 0,029 & 2,996 & 4,7 & 0,140 \\
\hline 7. & 4,5 & 0,029 & 2,996 & 4,6 & 0,137 \\
\hline 8. & 4,4 & 0,029 & 2,930 & 4,6 & 0,136 \\
\hline 9. & 4,4 & 0,028 & 2,897 & 4,8 & 0,139 \\
\hline 10. & 4,5 & 0,029 & 2,963 & 4,4 & 0,131 \\
\hline 11. & 4,7 & 0,031 & 3,128 & 4,3 & 0,134 \\
\hline 12. & 4,7 & 0,031 & 3,128 & 4,3 & 0,136 \\
\hline 13. & 4,6 & 0,030 & 3,062 & 4,7 & 0,145 \\
\hline 14. & 4,6 & 0,030 & 3,062 & 4,6 & 0,140 \\
\hline 15. & 4,6 & 0,030 & 3,062 & 4,6 & 0,142 \\
\hline 16. & 4,6 & 0,030 & 3,062 & 4,8 & 0,146 \\
\hline 17. & 4,7 & 0,030 & 3,095 & 4,4 & 0,137 \\
\hline 18. & 4,7 & 0,031 & 3,128 & 4,3 & 0,134 \\
\hline 19. & 4,7 & 0,030 & 3,095 & 4,7 & 0,145 \\
\hline 20. & 4,8 & 0,031 & 3,161 & 4,8 & 0,151 \\
\hline 21. & 4,5 & 0,029 & 2,963 & 4,5 & 0,133 \\
\hline 22. & 4,7 & 0,030 & 3,095 & 4,7 & 0,145 \\
\hline 23. & 4,6 & 0,030 & 3,029 & 4,6 & 0,139 \\
\hline 24. & 4,6 & 0,030 & 3,062 & 4,6 & 0,142 \\
\hline 25. & 4,8 & 0,031 & 3,161 & 4,8 & 0,151 \\
\hline 26. & 4,4 & 0,029 & 2,930 & 4,4 & 0,130 \\
\hline 27. & 4,3 & 0,028 & 2,831 & 4,3 & 0,121 \\
\hline 28. & 4,3 & 0,028 & 2,864 & 4,3 & 0,124 \\
\hline 29. & 4,7 & 0,031 & 3,128 & 4,6 & 0,143 \\
\hline 30. & 4,7 & 0,031 & 3,128 & 4,7 & 0,148 \\
\hline 31. & 4,6 & 0,030 & 3,062 & 4,7 & 0,143 \\
\hline 32. & 4,7 & 0,030 & 3,095 & 4,8 & 0,148 \\
\hline 33. & 4,5 & 0,029 & 2,963 & 4,5 & 0,133 \\
\hline $\begin{array}{c}\text { Total } \\
\text { Weighted }\end{array}$ & 151,85 & & 100 & & 4,604 \\
\hline $\begin{array}{c}\text { Total } \\
\text { Satisfaction } \\
\text { Index } \\
\end{array}$ & & & & & 0,920 \\
\hline
\end{tabular}

d. SDM sudah memenuhi

SDM dalam pengembangan unit usaha klinik HD skala UKM di RSIA Setya Bhakti sudah memenuhi, baik dokter dan perawat, tetapi untuk perawat belum memiliki sertifikat HD. Namun demikian pelayanan yang diberikan masyarakat pengguna HD sangat baik dan cepat, sehingga tingkat kepentingan terhadap atribut ini dinilai penting dengan nilai 4,7 dan penilaian kinerja dengan nilai 4,7, dengan skor tertimbang 0,148. Atribut ini menduduki peringkat keempat, sehingga layak untuk dipertahankan.

\section{Analisis IPA}

Dari Tabel 4 diperoleh perhitungan skor Likert, yaitu nilai rataan tingkat kinerja pelayanan 4,6 menunjukkan mutu pelayanan pada unit usaha klinik HD skala UKM adalah baik dan tingkat kepentingan pelayanan konsumen 4,6, yaitu sangat penting bagi konsumen. Secara garis besar terlihat bahwa kinerja pelayanan unit usaha klinik HD skala UKM telah sesuai dengan apa yang diharapkan masyarakat pengguna.

Berdasarkan tingkat kesesuaiannya dari Tabel 4, terlihat atribut layanan memiliki tingkat kesesuaian paling tinggi dan harus terus terus 
dipertahankan adalah (9) lokasi dekat dengan pelaku pasar, (3) jaringan pelaku pasar HD, (8) tenaga profesional dan (5) kebutuhan masyarakat terhadap pelayanan.

Rincian analisis dari masing-masing atribut yang dikaji pada Tabel 4 adalah:

a. Lokasi dekat dengan pelaku pasar

Lokasi unit usaha klinik HD skala UKM sangat dekat dengan masyarakat, khususnya daerah Depok. Penggunaan HD dengan jaminan BPJS sangat banyak, sehingga posisi lokasi unit usaha ini akan sangat memengaruhi pengembangan unit usaha klinik HD ini. Hasil perhitungan terhadap tingkat kepentingan pelanggan pada atribut ini 4,8 dan tingkat kinerja 4,4, serta tingkat kesesuaian 109,09, dimana pelanggan merasa atribut ini dinilai sangat baik, maka perlu dipertahankan dan tetap ditingkatkan.

b. Jaringan pelaku pasar hemodialisa

Jaringan pelaku pasar HD sangat bagus, karena penggunaan HD ini menggunakan BPJS sehingga pasar sudah jelas. Hasil perhitungan terhadap tingkat kepentingan pelanggan pada atribut ini 4,7 dan tingkat kinerja 4,4, serta tingkat kesesuaian 106,81, dimana pelanggan merasa bahwa atribut ini dinilai sangat baik, maka perlu dipertahankan dan terus ditingkatkan. Dalam hal ini pasien akan semakin puas apabila merasa mudah, nyaman dan efisien dalam mendapatkan pelayanan.

\section{c. Tenaga profesional}

Tenaga yang tersedia di unit usaha klinik HD skala UKM sangat profesional. Dokter dan perawat sebagai bagian penting dari klinik HD sudah sangat berpengalaman. Hal tersebut menunjukkan manajemen unit usaha klinik HD sudah siap dan berpengalaman. Hasil perhitungan terhadap tingkat kepentingan pelanggan pada atribut ini 4,6 dan tingkat kinerja 4,4, serta tingkat kesesuaian 104,49, dimana pelanggan merasa atribut ini dinilai sangat baik, maka perlu dipertahankan dan ditingkatkan.

d. Kebutuhan masyarakat terhadap pelayanan

Kebutuhan masyarakat pengguna terhadap pelayanan sangat penting. Untuk itu diusahakan menjaga mutu agar masyarakat pengguna klinik HD ini semakin banyak dan berkembang. Hasil perhitungan terhadap tingkat kepentingan pelanggan pada atribut ini 4,5 dan tingkat kinerja 4,3, serta tingkat kesesuaian 103,44, dimana pelanggan merasa atribut ini dinilai sangat baik, maka perlu dipertahankan dan ditingkatkan. Hasil penelitian menunjukkan frekuensi tindakan HD bervariasi, tergantung pada banyaknya fungsi ginjal yang tersisa, rataan penderita menjalani tiga kali dalam seminggu, sedangkan lama pelaksanaan HD paling sedikit tiga sampai empat jam tiap sekali tindakan terapi (Brunner dan Suddath, 2002; Yang et al., 2011).

\section{KESIMPULAN}

Berdasarkan kombinasi nilai EFE dan IFE didapatkan matriks IE yang menunjukkan posisi Pertumbuhan/Stabil. Hal ini menggambarkan dan mengindikasikan posisi usaha klinik HD stabil untuk merespon situasi pasar yang dihadapi. Kegiatan untuk peningkatan pemasaran dan pelayanan merupakan salah satu formulasi strategi yang dapat menjadi andalan utama bagi unit usaha klinik HD.

Dari hasil SWOT didapatkan strategi pengembangan, yaitu (1) permintaan semakin tinggi dan mutu hubungan RS dengan BPJS akan menghasilkan output layanan baik, mengingat tipe RS dapat merangkul semua kalangan, (2) meningkatkan daya saing RS untuk memberikan pelayanan yang lebih baik daripada RS sekitar penyedia HD, (3) menarik investor untuk menginvestasikan dana bagi klinik HD skala UKM, (4) mutu yang diberikan RSIA Setya Bhakti akan menanggalkan anggapan negatif tentang RS tipe D, (5) membangkitkan kepercayaan masyarakat terhadap layanan dan RS akan meningkatkan dan mengadakan lebih banyak alat HD, serta mengadakan perawat yang bersertifikat dan (6) meningkatan mutu dengan mengadakan lebih banyak alat dianalisis dan mengadakan perawat yang bersertifikat dalam menghadapi persaingan dengan RS sekitar penyedia HD.

Skor CSI 0,920, ini menunjukkan tingkat indeks kepuasan pelanggan terletak pada 0,81 1,00 , berarti pelanggan merasa sangat puas terhadap unit usaha klinik HD. Untuk skor IPA 4,60, menunjukkan mutu pelayanan pada unit usaha klinik HD skala UKM adalah baik. 
Tabel 4. Tingkat penilaian kinerja dan kepentingan

\begin{tabular}{|c|c|c|c|c|c|}
\hline $\begin{array}{c}\text { Daftar } \\
\text { Pertanyaan }\end{array}$ & $\begin{array}{c}\text { Penilaian } \\
\text { Kinerja }\end{array}$ & $\begin{array}{c}\text { Penilaian } \\
\text { Kepentingan }\end{array}$ & $x$ & Y & $\begin{array}{c}\text { Tingkat } \\
\text { Kesesuaian }\end{array}$ \\
\hline 1. & 96 & 93 & 4,8 & 4,6 & 103,22 \\
\hline 2. & 90 & 92 & 4,5 & 4,6 & 97,82 \\
\hline 3. & 94 & 88 & 4,7 & 4,4 & 106,81 \\
\hline 4. & 96 & 93 & 4,8 & 4,6 & 103,22 \\
\hline 5. & 90 & 87 & 4,5 & 4,3 & 103,44 \\
\hline 6. & 94 & 91 & 4,7 & 4,5 & 103,29 \\
\hline 7. & 92 & 91 & 4,6 & 4,5 & 101,09 \\
\hline 8. & 93 & 89 & 4,6 & 4,4 & 104,49 \\
\hline 9. & 96 & 88 & 4,8 & 4,4 & 109,09 \\
\hline 10. & 89 & 90 & 4,4 & 4,5 & 98,88 \\
\hline 11. & 86 & 95 & 4,3 & 4,7 & 90,52 \\
\hline 12. & 87 & 95 & 4,3 & 4,7 & 91,57 \\
\hline 13. & 95 & 93 & 4,7 & 4,6 & 102,15 \\
\hline 14. & 92 & 93 & 4,6 & 4,6 & 98,92 \\
\hline 15. & 93 & 93 & 4,6 & 4,6 & 100 \\
\hline 16. & 96 & 93 & 4,8 & 4,6 & 103,22 \\
\hline 17. & 89 & 94 & 4,4 & 4,7 & 94,68 \\
\hline 18. & 86 & 95 & 4,3 & 4,7 & 90,52 \\
\hline 19. & 94 & 94 & 4,7 & 4,7 & 100 \\
\hline 20. & 96 & 96 & 4,8 & 4,8 & 100 \\
\hline 21. & 90 & 90 & 4,5 & 4,5 & 100 \\
\hline 22. & 94 & 94 & 4,7 & 4,7 & 100 \\
\hline 23. & 92 & 92 & 4,6 & 4,6 & 100 \\
\hline 24. & 93 & 93 & 4,6 & 4,6 & 100 \\
\hline 25. & 96 & 96 & 4,8 & 4,8 & 100 \\
\hline 26. & 89 & 89 & 4,4 & 4,4 & 100 \\
\hline 27. & 86 & 86 & 4,3 & 4,3 & 100 \\
\hline 28. & 87 & 87 & 4,3 & 4,3 & 100 \\
\hline 29. & 92 & 95 & 4,6 & 4,7 & 96,84 \\
\hline 30. & 95 & 95 & 4,7 & 4,7 & 100 \\
\hline 31. & 94 & 93 & 4,7 & 4,6 & 101,07 \\
\hline 32. & 96 & 94 & 4,8 & 4,7 & 102,12 \\
\hline 33. & 90 & 90 & 4,5 & 4,5 & 100 \\
\hline Rataan & & & 4,60 & 4,60 & \\
\hline
\end{tabular}

\section{DAFTAR PUSTAKA}

Brunner \& Suddarth. 2002. Buku Ajar Keperawatan Medikal Bedah, Ed 8. Jakarta: EGC.

Chen, S.C., Chang, J.M., Hwang, S.J., Chen, J.H., Lin, F.H., Su, H.O. and Chen, H.C. 2009. Comparison of Ankle-Brachial Index and Brachial-Ankle Pulse Wave Velocity between Patients with Chronic Kidney Disease and Hemodialysis. Am J Nephrol, 29: 374-380.

David, F.R. 2006. Manajemen Strategi (Terjemahan). PT Prenhallindo, Jakarta.

Gallieni, M., Butti, A., Guazzi, M., Galassi, A., Cozzolino, M. and Brancaccio, D. 2008.Impaired Brachial Artery Endothelial Flow-Mediated Dilation and Orthostatic
Stress in Hemodialysis Patients. "e International Journal of Arti! cial Organs, 31(1): 34-42.

Hendriyani, E. 2010. Analisis Kepuasan Konsumen Terhadap Produk Roti "Breadhouse" Untuk Menentukan Strategi Pengembangan Usaha. Bogor (ID). Tesis pada Program Studi Pengembangan Industri Kecil Menengah Sekolah Pascasarjana Institut Pertanian Bogor.

Mailani, F. 2015. Kualitas Hidup Pasien Penyakit Ginjal Kronik yang Menjalani Hemodialisis: Systematic Review. Ners Jurnal Keperawatan, 11(1), Maret 2015: 1-8.

Orlic, L., Crncevic, Z., Pavlovic, D. and Zaputovic, L. 2010. Bone Mineral Densitometry in Patients On Hemodialysis: Difference 
Between Genders and What to Measure Bone Mineral Density in Hemodialysis Patients. Renal Failure, 32: 300-308.

PERNEFRI (Perhimpunan Nefrologi Indone-sia). 2003.Penyakit Ginjal Kronik dan Glomerulopati: Aspek Klinik dan Patologi Ginjal. PERNEFRI. Jakarta.

Rangkuti, F. 2013. Marketing Strategy \& Competitive Positioning. Jakarta (ID). PT. Gramedia Pustaka Utama.

Russell, M.R., Gómez, L.L.T., Domínguez, R.L.P., Santiago, R.E. and Cervantes, M.L. 2011. Work Climate in Mexican Heamodialysis. Units: A Cross-Sectional Study. Nefrologia, 31(1): 76-83.

Santos, P., B., Junior, J., Cavalcanti, J., U., Vieira, A., Rocha, A., R., M. 2012. Quality of life among women with sexual dysfunction undergoing hemo-dialysis: a cross sectional observational study. Health and quality of life outcomes, 10, 1-5

Sulistini, R., K. Yetti dan Rr T.S. Hariyati. 2012. Faktor-Faktor yang Mempengaruhi Fatigue pada Pasien yang Menjalani Hemodialisis. Jurnal Keperawatan Indonesia, 15(2) 75-82.

Supriyadi, Wagiyo dam Widowati. 2011. Tingkat kualitas hidup pasien gagal ginjal kronik terapi Hemodialisis. Jurnal Kesehatan Masyarakat, 6(2) 107-112.

Umar, H. 2003. Riset Pemasaran dan Perilaku Konsumen. Jakarta (ID). PT. Gramedia Pustaka Utama.

Yang, L., Lin, Y., Ye, C., Mao, Z., Rong, S., Zhao, X. and Mei, C. 2011.E\# ects of Peritoneal Dialysis and Hemodialysis on Arterial Stiffness Compared with Predialysis Patients. Clinical Nephro-logy, 75 (3): 188194.

Yong, D.S.P., Kwok, A.O.L., Wong, D.M.L. 2009. Symptom burden and quality of life in end stage renal disease: a study of 179 patients on dialysis and palliative care. Palliative medicine Journal 23, 111-119.DOI 10.1177/ 0269216308101099 . 